\title{
The relationship between leisure constraints, technology addiction and life satisfaction: a study on Turkish university students
}

\author{
Emrah Serdar $^{\mathrm{a} *}$, Mehmet Demirel $^{\mathrm{b}}$ \\ ${ }^{a}$ Istanbul University-Cerrahpaşa, Faculty of Sport Science, Istanbul, 34320, Turkey \\ ${ }^{b}$ Necmettin Erbakan University, Faculty of Tourism, Meram/Konya,42090,Turkey
}

\begin{abstract}
This study aimed to determine the relationship between leisure constraints, technology addictions and life satisfaction of university students. The sample of the study consisted of a total of 234 people who were studying at Istanbul University-Cerrahpaşa Faculty of Sports Sciences. As a data collection tool, "Leisure Constraints Scale-Short Form (LCS-SF)", "Technology Addiction Scale (TAS)" and "Life satisfaction Scale (LSS)" were used as a data collection tool. İndependent t-Test, ANOVA, MANOVA and Pearson Correlation analysis were used. According to MANOVA analysis, the main effect of gender and weekly leisure on LCS and TAS was significant. According to Pearson Correlation analysis, it was found that there was a positive and low relationship between the "Individual Psychology", "Lack of Friends", "Time" and "Lack of Interest" sub-dimensions of LCS and the subdimensions of "Social Network Addiction", "Instant Messaging Addiction" and "Web Site Addiction" of TAS. As a result, it can be said that the LCS, TAS and LSS scores differed according to the sociodemographic characteristics of the participants, and as the leisure constraints of the individuals increased, their technology addiction also increased.
\end{abstract}

Keywords: leisure constraints; technology addiction; life satisfaction; university students

\section{Introduction}

The technology developing with globalization, besides being an indispensable element in meeting some of our needs at every moment of our lives (Karadağ and K1lıç, 2019), has also revealed the technology addiction, which is one of the biggest problem areas of the new generation (Yam and İlhan, 2020; Demirci et al. 2014; Pugh 2017; Wang et al. 2017). From this point of view, technology addiction regarding the usage of the internet and technological devices defined as excessive use, inability to satisfy the desire to use, neglecting activities due to excessive use, excessive use harming social relations, using it as an escape tool from negative emotions and life stress, experiencing problems in reducing and stopping use, being nervous and irritable when use is not possible, and lying about the duration and amount of use (Ektiricioğlu, 2020; Kwon et al., 2013; Griffiths, 1995; Young, 1997). Beard (2005), on the other hand, has expressed technology addiction as the damage to the mental and emotional psychological state of individuals, their professional and social interactions, due to excessive use of technology (Ertemel and Pektaş, 2018). Technological addictions are considered as behavior-based addictions, and in such addictions, individuals can become passive addicts by watching television, but they can also become active technology addicts with technological tools such as digital

* Corresponding author. Tel.: +0212 40403 00; fax: +90 2124737253

E-mail address: serdar-emrah@ @otmail.com 
games, internet, mobile phone, computer (Gökel, 2020; Bachleda \& Darhiri, 2018; Öztürk, 2017). Moreover, Jackson et al., (2011) stated that technology addiction has negative effects such as developmental problems, posture disorders, personality disorders, dry eyes, headache, aggressive attitude development, boredom, desire to escape from reality, increased level of anxiety, learning disorders, low academic achievement (Emre et al., 2019).

Technological developments have caused a decrease in the working hours of individuals and an increase in leisure accordingly. This situation has also increased the interest in the leisure participation and the problem of participation in leisure (Yerlisu Lapa and Köse, 2018). Demirel and Harmandar (2009), on the other hand, have stated that despite the positive contributions of participation in leisure activities, individuals do not participate in such activities, which are very important for them for various reasons or cannot participate due to various constraints. From this point of view, the leisure constraints model was first developed by Crawford and Godbey in 1987 (Barbosa and Liechty, 2018) and defined as the factors that affect individuals to form their leisure preferences for certain activities and limit their ability to participate in activities (Jackson and Scott, 1999; Lyu and Oh, 2014). According to another definition, leisure activities can be expressed as factors that prevent active participation or limited satisfaction in leisure activities (Jackson, 1988; Lee et al., 2020). Crawford and Godbey (1987) classify leisure constraints in three categories as individual, interpersonal and structural constraints (Alexandris et al., 2017). In this context, the leisure constraints are respectively, Individual constraints; It includes individual psychological states and qualities that interact with leisure preferences rather than intervening between choices and participation (Crawford et al., 1991; Andronikidis et al., 2007). Interpersonal constraints; results from an individual's interactions with others (Lyu et al., 2013). Structural constraints are defined as factors that interfere between leisure preferences and participation (such as cost, time and transportation) (Jun \& Kyle, 2011).

Life satisfaction, which is an evaluation at the cognitive level, is expressed as individuals' positive evaluations of their lives according to their own criteria (Öngel \& Tatl1, 2020). In other words, life satisfaction expresses how much individuals enjoy the life they live (Diener et al., 1998; Argan and Mersin, 2021). Also, life satisfaction is usually an indicator of general health and wellbeing, associated with longevity (Pescaru, 2017). Life satisfaction of individuals can be affected by the happiness gained from daily life, meaning attributed to life, harmony in reaching goals, positive individual identity, physical well-being of the individual, economic security and social relations (Pavot \& Diener, 2008; Kara et al., 2018). Similarly, Rojas (2006) has stated that the extent to which satisfaction in some areas of life contributes to general life satisfaction changes throughout life and with important life events (Ramia \& Voicu, 2020). In this context, this study aimed to determine the relationship between leisure constraints, technology addictions and life satisfaction of university students.

\section{Methodology}

\subsection{Research Model}

Relational screening model was used in the research following the aim of the study. In the relational screening model, questions such as the degree of change between the variables or the level of the examined situation clarified with relational screening designs (Gürbüz \& Şahin, 2016).

\subsection{Research Group}

The study group of the research consisted of a total of 234 people, 124 male $\left(\right.$ Mean $\left._{\text {age }}=22.41 \pm 4.36\right)$ and 110 female $\left(\right.$ Mean $\left._{\text {age }}=20.68 \pm 2.81\right)$, who were studying at Istanbul University-Cerrahpaşa Faculty of Sports Sciences, and selected by purposeful sampling method. Moreover, it was determined that $52.6 \%$ of the participants used the 
internet between "4-7 Hours" daily, 32.9\% of them had a weekly "6-10 Hours" of leisure, while $70.5 \%$ of them had "Normal" welfare status.

\subsection{Data Collection Tools}

2.3.1. Personal Information Form: The "Personal Information Form" was prepared by the researcher to obtain information about the gender, age, welfare status, daily internet use and weekly leisure periods of the participants in the study.

2.3.2. Leisure Constraints Scale-Short Form (LCS-SF): The "Leisure Constraints Scale-Short Form (LCS-SF)" developed by Alexandris and Carroll (1997) to determine the factors that prevent individuals from participating in leisure activities, and adapted to Turkish by Gürbüz et al., (2020). The scale consisted of 18 items and 6 sub-dimensions. The sub-dimensions were respectively; "Individual Psychology", "Lack of Knowledge", "Facilities", "Lack of Friends", "Time" and "Lack of Interest". Items in the scale were scored as (1) Absolutely Unimportant, (4) Very Important. The internal consistency coefficients for the sub-dimensions were respectively; .77, $.86, .80, .81, .65$ and .76 . In this study, the internal consistency coefficients for the sub-dimensions were respectively; $.71, .79, .75, .84, .64$ and .60 .

2.3.3. Technology Addiction Scale (TAS): The "Technology Addiction Scale" developed by Aydin (2017) to determine the technology addictions of the participants. The scale consisted of 24 items and 4 sub-dimensions. The sub-dimensions were respectively; "Social Network Addiction", "Instant Messaging Addiction", "Online Gaming Addiction", "Web Site Addiction". Items in the scale were scored as (1) Never, (5) Always. The internal consistency coefficients for the sub-dimensions are respectively; $.78, .80, .89$ and .86 . In this study, the internal consistency coefficients for the sub-dimensions determined as $.77, .78, .91$ and .87 , respectively.

2.3.4. Life Satisfaction Scale (LSS): The "Satisfaction with Life Scale" developed by Diener et al. (1985) to determine the life satisfaction levels of the participants, and adapted into Turkish by Yetim (1993). The scale was one-dimensional and consisted of 5 items. Items in the scale were scored as (1) Strongly Disagree, (7) Strongly Agree. The internal consistency coefficient of the scale was determined as .86. In this study, the reliability coefficient of the scale was determined as .79.

\subsection{Data analysis}

SPSS 20.0 package program was used in the analysis of the data. Percentage and frequency methods were used to determine the distribution of the participants' personal information. In order to determine whether the data showed a normal distribution, skewness and kurtosis values were examined and it was understood that the data showed a normal distribution. In this context, in the analysis of the data; independent t-test, ANOVA, MANOVA and Pearson Correlation analyzes were used. Finally, Cronbach Alpha coefficients were calculated to determine the reliability of the scales. 


\section{Results}

Table 1. Distribution of scale scores

\begin{tabular}{cccccccc}
\hline \multirow{2}{*}{ Sub-dimensions } & $\begin{array}{c}\text { Item } \\
\text { Number }\end{array}$ & $\mathbf{n}$ & Mean & Sd. & Skewness & Kurtosis \\
\hline \multirow{5}{*}{ LCS } & Individual Psychology & 3 & 234 & 2.76 & 0.64 & -0.53 & 0.42 \\
\cline { 2 - 7 } & Lack of Knowledge & 3 & 234 & 3.10 & 0.64 & -0.98 & 1.93 \\
\cline { 2 - 7 } & Facilities & 3 & 234 & 3.21 & 0.61 & -0.92 & 1.76 \\
\cline { 2 - 7 } & Lack of Friends & 3 & 234 & 2.64 & 0.72 & -0.04 & -0.35 \\
\cline { 2 - 7 } & Time & 3 & 234 & 3.01 & 0.53 & -0.56 & 1.66 \\
\hline \multirow{3}{*}{ TAS } & Lack of Interest & 3 & 234 & 2.72 & 0.60 & -0.30 & 0.69 \\
\cline { 2 - 7 } & Social Network Addiction & 6 & 234 & 2.50 & 0.81 & 0.37 & 0.38 \\
\cline { 2 - 7 } & Instant Messaging Addiction & 6 & 234 & 2.52 & 0.80 & 0.30 & 0.27 \\
\cline { 2 - 7 } & Online Gaming Addiction & 6 & 234 & 2.23 & 1.06 & 0.41 & -0.70 \\
\cline { 2 - 7 } LSS & Web Site Addiction & 6 & 234 & 2.43 & 0.99 & 0.47 & -0.27 \\
\hline
\end{tabular}

When the mean scores of the individuals included in the study from the subdimensions of the scale in Table 1 were examined, it was determined that the highest mean was in the "Facilities" (3.21) sub-dimension at the sub-dimension level of LCS, and the lowest mean was in the "Lack of Friends" (2.64) sub-dimension. At the subdimensions level of TAS, it was determined that the highest mean was in the "Instant Messaging Addiction" (2.52) sub-dimension, while the lowest mean was in the "Online Gaming Addiction" (2.23) sub-dimension. The mean score of the participants on the LSS was determined as (3.86).

Table 2. Analysis results of LCS, TAS, and LSS scores according to gender

\begin{tabular}{lcccc}
\hline Scales & \multicolumn{2}{c}{ Male $(\boldsymbol{n}=\mathbf{1 2 4})$} & \multicolumn{2}{c}{ Female $(\boldsymbol{n}=110)$} \\
& Mean & Sd. & Mean & Sd. \\
\hline LCS & & & & \\
$\quad$ Individual Psychology & 2.57 & 0.69 & 2.98 & 0.49 \\
$\quad$ Lack of Knowledge & 3.04 & 0.63 & 3.18 & 0.64 \\
$\quad$ Facilities & 3.14 & 0.65 & 3.30 & 0.56 \\
$\quad$ Lack of Friends & 2.68 & 0.69 & 2.59 & 0.76 \\
$\quad$ Time & 2.95 & 0.55 & 3.07 & 0.49 \\
$\quad$ Lack of Interest & 2.72 & 0.57 & 2.73 & 0.63 \\
\hline TAS & & & & \\
$\quad$ Social Network Addiction & 2.52 & 0.82 & 2.48 & 0.79 \\
$\quad$ Instant Messaging Addiction & 2.54 & 0.82 & 2.50 & 0.79 \\
$\quad$ Online Gaming Addiction & 2.49 & 0.96 & 1.94 & 1.09 \\
$\quad$ Web Site Addiction & 2.50 & 0.95 & 2.34 & 1.02 \\
\hline LSS & 3.77 & 1.21 & 3.96 & 1.49 \\
\hline
\end{tabular}

In Table 2, the results of the analysis according to the gender of the participants in the research were given. MANOVA analysis results, it was determined that the main effect of the gender of the participants on the sub-dimensions of LCS was significant $[\lambda=0.878, \mathrm{~F}(6,227)=5.239 ; \mathrm{p}<0.05]$. At the level of sub-dimensions, there was a significant difference only in the sub-dimension "Individual Psychology" [F (1-232) $=6.045 ; \mathrm{p}<0.05]$. Female's mean scores were higher than scores of the male. According to the results of MANOVA analysis, it was determined that the main effect of the gender of the individuals on the sub-dimensions of TAS was significant $[\lambda=$ 0.905 , F $(4,229)=6.004 ; \mathrm{p}<0.05]$. However, it was determined that there was a significant difference only in the "Online Gaming Addiction" sub-dimension at the sub-dimensions level $[\mathrm{F}(1-232)=16.692 ; \mathrm{p}<0.05]$. It was determined that the scores of the male were higher than female's subscale scores. According to the Independent $\mathrm{t}$-Test results, no statistically significant difference was found between the LSS scores of the participants according to their gender $(\mathrm{t}=-1.055 ; \mathrm{p}>0.05)$. 
Table 3. Analysis results of LCS, TAS, and LSS scores according to participants' daily internet usage

\begin{tabular}{|c|c|c|c|c|c|c|}
\hline \multirow{2}{*}{ Scales } & \multicolumn{2}{|c|}{$\begin{array}{c}3 \text { hours and less } \\
(n=46)\end{array}$} & \multicolumn{2}{|c|}{$\begin{array}{r}4-7 \text { hours } \\
(n=123)\end{array}$} & \multicolumn{2}{|c|}{$\begin{array}{c}8 \text { hours and above } \\
(n=65)\end{array}$} \\
\hline & Mean & Sd. & Mean & Sd. & Mean & Sd. \\
\hline \multicolumn{7}{|l|}{ LCS } \\
\hline Individual Psychology & 2.64 & 0.61 & 2.76 & 0.65 & 2.86 & 0.61 \\
\hline Lack of Knowledge & 3.06 & 0.65 & 3.07 & 0.65 & 3.20 & 0.60 \\
\hline Facilities & 3.14 & 0.56 & 3.16 & 0.62 & 3.36 & 0.61 \\
\hline Lack of Friends & 2.37 & 0.69 & 2.64 & 0.73 & 2.82 & 0.69 \\
\hline Time & 2.98 & 0.48 & 3.00 & 0.56 & 3.05 & 0.50 \\
\hline Lack of Interest & 2.62 & 0.63 & 2.70 & 0.57 & 2.84 & 0.61 \\
\hline \multicolumn{7}{|l|}{$\overline{\text { TAS }}$} \\
\hline Social Network Addiction & 2.40 & 0.86 & 2.47 & 0.71 & 2.63 & 0.94 \\
\hline Instant Messaging Addiction & 2.30 & 0.82 & 2.56 & 0.64 & 2.59 & 1.02 \\
\hline Online Gaming Addiction & 2.02 & 1.08 & 2.23 & 0.98 & 2.39 & 1.17 \\
\hline Web Site Addiction & 2.12 & 1.00 & 2.44 & 0.92 & 2.61 & 1.06 \\
\hline LSS & 3.50 & 1.33 & 4.04 & 1.39 & 3.76 & 1.26 \\
\hline
\end{tabular}

In Table 3, the results of the analysis according to the daily internet usage of the participants in the research were given. According to MANOVA analysis results, it was determined that the main effect of the participants' daily internet usage on the sub-dimensions of LCS was not significant $[\lambda=0.928$, F $(12,452)=1.438 ; \mathrm{p}>0.05]$. However, at the sub-dimensions level, there was a statistically significant difference only in the "Lack of Friends" sub-dimension [F $(2-231)=5.283 ; \mathrm{p}<0.05]$. The mean scores of individuals who used the Internet for 8 hours or more per day were higher than the scores of other individuals. According to the results of MANOVA analysis, it was determined that the main effect of the participants' daily internet usage on the sub-dimensions of TAS was not significant $[\lambda=0.951, F(8,456)=1.460 ; p>0.05]$. At the level of sub-dimensions, there was a statistically significant difference only in the sub-dimension "Web site Addiction " [F (2-231) =3.307; $\mathrm{p}<0.05]$. The sub-dimension scores of individuals who used the internet for 8 hours or more per day were higher than the scores of other individuals. According to the results of ANOVA analysis, no significant difference was found between the LSS scores according to the daily internet usage of individuals ( $\mathrm{f}=2.918 ; \mathrm{p}>0.05)$.

Table 4. Analysis results of LCS, TAS, and LSS scores according to participants' weekly leisure

\begin{tabular}{|c|c|c|c|c|c|c|c|c|}
\hline \multirow{2}{*}{ Scales } & \multicolumn{2}{|c|}{$\begin{array}{l}\text { 1-5 hours } \\
(n=40)\end{array}$} & \multicolumn{2}{|c|}{$\begin{array}{c}\text { 6-10 hours } \\
(n=77)\end{array}$} & \multicolumn{2}{|c|}{$\begin{array}{c}\text { 11-15 hours } \\
\quad(n=42)\end{array}$} & \multicolumn{2}{|c|}{$\begin{array}{c}16 \text { hours and above } \\
(n=75)\end{array}$} \\
\hline & Mean & Sd. & Mean & Sd. & Mean & Sd. & Mean & Sd. \\
\hline \multicolumn{9}{|l|}{$\overline{\mathrm{LCS}}$} \\
\hline Individual Psychology & 2.85 & 0.72 & 2.80 & 0.56 & 2.68 & 0.57 & 2.72 & 0.70 \\
\hline Lack of Knowledge & 3.05 & 0.82 & 3.01 & 0.62 & 3.15 & 0.50 & 3.20 & 0.61 \\
\hline Facilities & 3.25 & 0.84 & 3.11 & 0.58 & 3.16 & 0.44 & 3.32 & 0.57 \\
\hline Lack of Friends & 2.35 & 0.67 & 2.76 & 0.72 & 2.72 & 0.69 & 2.62 & 0.74 \\
\hline Time & 3.15 & 0.48 & 3.03 & 0.51 & 2.96 & 0.54 & 2.93 & 0.55 \\
\hline Lack of Internet & 2.65 & 0.74 & 2.75 & 0.53 & 2.64 & 0.63 & 2.79 & 0.57 \\
\hline \multicolumn{9}{|l|}{ TAS } \\
\hline Social Network Addiction & 2.35 & 0.87 & 2.57 & 0.73 & 2.39 & 0.82 & 2.57 & 0.84 \\
\hline Instant Messaging Addiction & n 2.30 & 0.82 & 2.58 & 0.67 & 2.54 & 0.93 & 2.56 & 0.84 \\
\hline Online Gaming Addiction & 2.00 & 0.96 & 2.33 & 0.95 & 2.12 & 1.09 & 2.32 & 1.19 \\
\hline Web Site Addiction & 2.08 & 0.92 & 2.44 & 0.89 & 2.34 & 1.03 & 2.64 & 1.05 \\
\hline LSS & 3.51 & 1.35 & 4.14 & 1.35 & 3.78 & 1.31 & 3.79 & 1.34 \\
\hline
\end{tabular}

In Table 4, the results of the analysis according to the weekly leisure of the participants in the research were given. According to MANOVA analysis results, it was determined that the main effect of the participants' weekly leisure on the subdimensions of LCS was significant $[\lambda=0.857, \mathrm{~F}(18,636)=1.981 ; \mathrm{p}<0.05]$. At the sub- 
dimensions level, there was a statistically significant difference only in the "Lack of Friends" sub-dimension $[\mathrm{F}(3-230)=3.151 ; \mathrm{p}<0.05]$. The mean scores of individuals who had 6-10 hours of leisure per week were higher than the scores of other individuals. According to the MANOVA analysis results, it was determined that the main effect of the participants' weekly leisure on the sub-dimensions of TAS was significant $[\lambda=0.937, \mathrm{~F}(12,600)=1.254 ; \mathrm{p}<0.05]$. However, at the level of subdimensions, there was a statistically significant difference only in the sub-dimension "Web site Addiction" [F $(3-230)=2.985 ; \mathrm{p}<0.05]$. The mean scores of individuals who had 16 hours or more of leisure per week were higher than the scores of other individuals. According to the results of ANOVA analysis, no significant difference was found between the LSS scores of the individuals according to their weekly leisure $(\mathrm{f}=2.152 ; \mathrm{p}>0.05)$.

Table 5. Results of Correlation Analysis between LSS, TAS and LCS Scores

\begin{tabular}{|c|c|c|c|c|c|c|c|c|c|c|c|}
\hline & $\mathrm{F} 1$ & $\mathrm{~F} 2$ & F3 & F4 & F5 & F6 & F7 & F8 & F9 & F10 & F11 \\
\hline F1 & 1 & & & & & & & & & & \\
\hline F2 & $.398^{*}$ & 1 & & & & & & & & & \\
\hline F3 & $.264^{*}$ & $.485^{*}$ & 1 & & & & & & & & \\
\hline $\mathrm{F} 4$ & $.185^{*}$ & $.203^{*}$ & $.158^{*}$ & 1 & & & & & & & \\
\hline F5 & $.365^{*}$ & $.318^{*}$ & $.367^{*}$ & $.326^{*}$ & 1 & & & & & & \\
\hline F6 & $.228^{*}$ & $.268^{*}$ & $.267^{*}$ & $.309^{*}$ & $.268^{*}$ & 1 & & & & & \\
\hline F7 & $.131^{*}$ & .102 & .014 & $.458^{*}$ & $.198^{*}$ & $.244^{*}$ & 1 & & & & \\
\hline F8 & $.182^{*}$ & .126 & .008 & $.387^{*}$ & $.173^{*}$ & $.198^{*}$ & $.753^{*}$ & 1 & & & \\
\hline F9 & .053 & .083 & .081 & .378 & .119 & .212 & $.561^{*}$ & $.575^{*}$ & 1 & & \\
\hline F10 & $.140^{*}$ & .011 & .070 & $.317^{*}$ & $.133^{*}$ & $.193^{*}$ & $.700^{*}$ & $.677^{*}$ & $.632^{*}$ & 1 & \\
\hline F11 & .153 & .094 & .096 & .042 & .037 & .034 & -.101 & .010 & .105 & -.083 & 1 \\
\hline
\end{tabular}

Table 5 showed the results of the pearson correlation analysis of LCS, TAS, and LSS scores. According to the analysis results, there was a positive and low correlation between the "Individual Psychology", "Lack of Friends", "Time" and "Lack of Interest" sub-dimensions of TAS and the sub-dimensions of "Social Network Addiction", "Instant Messaging Addiction" and "Web Site Addiction" of TAS level of relationship was found. It was determined that there was no relationship between LCS and LSS. Again, it was determined that there was no relationship between TAS and LSS.

\section{Discussions}

This study aimed to determine the relationship between leisure constraints, technology addictions and life satisfaction of students studying at the university. The results obtained for this aim were discussed and interpreted in this section.

It was determined that the main effect of the gender of the participants on the subdimensions of LCS was significant and the individual psychology sub-dimension scores of females were higher than male. This can be explained by the fact that female face more constraints than male during their psychological participation in leisure activities. When the studies in the literature on the subject were examined, the results of the research conducted by Ayhan et al., (2018), Soyer (2019) and Demirel et al., (2017) showed parallelism with the results of this research. It was determined that the main effect of gender on the sub-dimensions of TAS was significant. At the subdimensions level, it was determined that the mean scores of males in the subdimension of online gaming addiction were higher than the mean scores of females. This can be explained by the fact that male was more likely to play online games on the Internet than females. In the study conducted by Aydin (2017), examining students' views on the problems caused by technology addiction in the classroom 
environment, it was determined that the online gaming addiction levels of males were higher than females. From this point of view, the results of the study by Aydin (2017) showed parallelism with the results of this study. It was determined that there was no significant difference between the LSS scores of males and females according to their gender. This can be interpreted as the fact that the satisfaction levels that female or male generally get from life did not differ. In this context, when the studies in the literature on the subject were examined, the results of the study conducted by Kara et al., (2018), Çakır et al., (2016) and Elçi et al., (2019) showed parallelism with the results of this study.

It was determined that the main effect of individuals' daily internet usage time on the sub-dimensions of LCS was not significant, but there was a significant difference only in the "Lack of Friends" sub-dimension at the sub-dimensions level. It was determined that the mean scores of individuals who used the internet for 8 hours or more per day were higher than the scores of other individuals. This can be interpreted as individuals who used the internet for 8 hours or more per day and encounter constraints in their participation in leisure activities due to the lack of friends. It was determined that the main effect of daily internet usage on the sub-dimensions of TAS was not significant. At the level of sub-dimensions, it was determined that the mean scores of individuals who used the Internet for 8 hours or more per day only in the sub-dimension of "Web site Addiction" were higher than the mean scores of other individuals. This can be explained as individuals dedicating a significant part of their time to using websites after completing the tasks that they were responsible for on a daily basis. Although the life satisfaction scores of individuals with a daily internet usage of 4-7 hours were higher, no statistically significant difference was found. This situation can be interpreted as the daily internet usage of individuals was not an important variable in determining their life satisfaction levels.

It was determined that the main effect of the weekly leisure on the sub-dimensions of LCS was significant, and at the sub-dimension level, only the mean scores of the individuals who had 6-10 hours of free time per week in the "Lack of Friends" subdimension were higher than the scores of other individuals. This can be explained by the fact that individuals who had 6-10 hours of leisure per week encounter constraints in their leisure due to lack of friends. It was determined that the main effect of the participants' weekly leisure on the sub-dimensions of TAS was significant. At the subdimensions level, the "Web Site Addiction" sub-dimension scores of the participants who had 16 hours or more of leisure per week were found to be higher than the subdimension scores of the other individuals. In other words, it can be stated that individuals who had 16 hours or more of leisure per week prefer to use websites to evaluate their leisure. No statistically significant difference found between the LSS scores of the individuals according to the weekly leisure periods. Although the LSS scores of the individuals who had leisure between 6-10 hours a week were higher than the scores of the other individuals, and this difference was not significant. This can be explained by the fact that the weekly leisure of the participants was not an important variable in determining their life satisfaction.

It was found that there was a positive and low correlation between the "Individual Psychology", "Lack of Friends", "Time" and "Lack of Interest" sub-dimensions of LCS and the sub-dimensions of "Social Network Addiction", "Instant Messaging Addiction" and "Web Site Addiction" of TAS. In other words, it can be explained the more technology addiction increased, the level of constraints faced by individuals in leisure also increased. It was determined that there was no relationship between the sub-dimensions of LCS and the LSS. When the studies in the literature on the subject were examined, while the results of the study conducted by Soyer et al., (2017) and the results of this study showed parallelism, the results of the study conducted by Turan et al., (2019) did not support the results of this study. Finally, it was determined that there was no relationship between TAS sub-dimension scores and LSS scores. This situation can be explained as there was no relationship between the technological addictions of the participants and their life satisfaction. 


\section{Conclusion}

While women faced more obstacles in terms of psychology in their leisure, it was understood that male had higher levels of online gaming addiction. It was seen that individuals who used the internet for 8 hours or more per day encounter constraints due to lack of friends in their leisure, and individuals who used the internet for 8 hours or more per day prefer to use websites in this period. While individuals who had 6-10 hours of leisure per week were more likely to encounter constraints in their leisure participation due to lack of friends, it was determined that the level of website addiction was higher for the participants who had 16 hours or more per week. Finally, it can be said that as the leisure time constraints of the participants increased, their technology addiction also increased.

\section{References}

1. Alexandris K. \& Carroll B. (1997). An analysis of leisure constraints based on different recreational sport participation levels: Results from a study in Greece. Leisure Sciences, 19(1), $1-15$.

2. Alexandris, K., Du, J., Funk, D. \& Theodorakis, N.D. (2017). Leisure constraints and the psychological continuum model: A study among recreational mountain skiers. Leisure Studies, 36(5), 670-683.

3. Andronikidis, A., Vassiliadis, C.A., Priporas, C. \& Kamenidou, I. (2007). Examining leisure contraints for ski centre visitors: İmplications for services marketing. Journal of Hospitality \& Leisure Marketing. 15(4), 69-86.

4. Argan, M.T. \& Mersin, S. (2021). Life satisfaction, life quality and leisure satisfaction in health professionals. Perspectives in Psychıatric Care. 57(2), 660-666.

5. Aydın, F. (2017). Teknoloji bağımlılığının sınıf ortamında yarattığı sorunlara ilişkin öğrenci görüşleri. Ankara Üniversitesi Eğitim Bilimleri Enstitüsü, Ankara, Yüksek Lisans Tezi.

6. Ayhan, C., Ekinci, N.E., Yalçın, İ. \& Yiğit, Ş. (2018). İnvestigation of constraints that occur during participation in leisure activities by high school students: A sample of Turkey. Education Sciences. 8(2), 1-9.

7. Bachleda, C. \& Darhiri, L. (2018). Internet addiction and mental and physical fatigue. International Technology Management Review. 7(1), 25-33.

8. Barbosa, C. \& Liechty, T. (2018). Exploring leisure constraints among lesbian women who attend a straight-friendly church. Journal of Leisure Research. 49(2), 91-108.

9. Beard, K. W. (2005). Internet addiction: A review of current assessment techniques and potential assessment questions. CyberPsychology \& Behavior, 8(1), 7-14.

10. Crawford, D. W., \& Godbey, G. (1987). Reconceptualizing barriers to family leisure. Leisure Sciences, 9(2), 119-127.

11. Crawford, D.W., Jackson, E.L., \& Godbey, G. (1991). A hierarchical model of leisure constraints. Leisure Sciences, 13(4), 309-320.

12. Ç̧akır, V.O., Şahin, S., Serdar, E. \& Parlakkılıç, Ş. (2016). An examination of public employees the level of constraint of leisure and life satisfaction. Journal of Tourism Theory and Research, 2(2), 135-141.

13. Demirci, K., Orhan, H., Demirdaş, A., Akpinar, A. \& Sert, H. (2014). Validity and reliability of the Turkish version of the smartphone addiction scale in a younger population. Bulletin of Clinical Psychopharmacology, 24(3), 226-234.

14. Demirel, M. \& Harmandar D. (2009). Üniversite öğrencilerinin rekreasyonel etkinliklere katılımlarında engel oluşturabilecek faktörlerin belirlenmesi. Uluslararası İnsan Bilimleri Dergisi. 6(1), 838-846.

15. Demirel, M., Demirel, D.H. \&. Serdar, E. (2017). Constraints and perceived freedom levels in the leisure of university students. Journal of Human Sciences. 14(1), 789-795.

16. Diener, E., Sapyta, J.J. \& Suh, E. (1998). Subjective well-being is essential to well-being. Psychological Inquiry. 9(1), 33-37.

17. Diener, E., Emmons, R.A., Larsen, R.J. \& Griffin, S. (1985). The satisfaction with life scale. Journal of Personality Assessment. 49(1), 71-75.

18. Ektiricioğlu, C., Arslantaş, H. \& Yüksel, R. (2020). Ergenlerde çağın hastalığı: Teknoloji bağımlılığı. Arşiv Kaynak Tarama Dergisi. 29(1),51-64. 
19. Elçi, G., Doğan, M. \& Gürbüz, B. (2019). Bireylerin rekreasyonda algılanan sağlık çıktıları ve yaşam doyumu düzeylerinin incelenmesi. Uluslararası Spor, Egzersiz \& Antrenman Bilimi Dergisi. 5(3), 93-106.

20. Emre, O., Ulutaş, A., Nisan, F., Görgen, A.N. \& Cumurcu, H.B. (2019). Üniversite ögrencilerinde teknoloji ve internet bağımlılığı arasındaki ilişkinin incelenmesi. Batman University Journal of Life Sciences. 9(2), 167-182.

21. Ertemel, A.V. \& Pektaş, G.Ö.E. (2018). Dijitalleşen dünyada tüketici davranışları açısından mobil teknoloji bağımlılığı: Üniversite öğrencileri üzerine nitel bir araştırma. Yııldız Sosyal Bilimler Enstitüsü Dergisi. 2(2), 18-34.

22. Gökel, Ö. (2020). Teknoloji bağımlılığının çeşitli yaş gruplarındaki çocuklara etkileri hakkındaki ebeveyn görüşleri. Kıbrıs Türk Psikiyatri ve Psikoloji Dergisi, 2(1), 41-47.

23. Griffiths M.D. (1995). Technological addictions. Clinical Psychology Forum. 76, 14-19.

24. Gürbüz, S. \& Şahin, F. (2016). Sosyal bilimlerde araştırma yöntemleri. Gözden Geçirilmiş ve Güncellenmiş 3. Basım. Ankara: Seçkin Yayıncılık.

25. Gürbüz, B., Öncü, E. \& Emir, E. (2020). Boş zaman engelleri ölçeği: Kısa formunun yapı geçerliğinin test edilmesi. Spor ve Performans Araştırmaları Dergisi. 11(2), 120-131.

26. Jackson, E. L. (1988). Leisure constraints: A survey of past research. Leisure Sciences, 10(3), 203- 215 .

27. Jackson, E. L., \& Scott, D. (1999). Constraints to leisure. In E. L. Jackson \& E. L. Burton, T.L. (Eds.), Leisure studies: Prospects for the twenty-first century (pp. 299-321). State College, PA: Venture.

28. Jackson, L.A., Eye, A.V., Fitzgerald, H. E., Witt, E. A. \& Zhao Y. (2011). Internet use, videogame playing and cell phone use as predictors of children's body mass index (BMI), body weight, academic performance, and social and overall self-esteem. Computers in Human Behavior, 27(1), 599-604.

29. Jun, J. \& Kyle, G.T. (2011). The effect of identity conflict/facilitation on the experience of constraints to leisure and constraint negotiation. Journal of Leisure Research, 43(2), 176-204.

30. Kara, F.M., Gürbüz, B., Kılıç, S.K. \& Öncü, E. (2018). An investigation of pre-service physical education teachers' leisure boredom, life satisfaction and social connectedness. Journal of Computer and Education Research. 6(12), 342-357.

31. Karadă̆, E. \& Kılıç, B. (2019). Öğretmen görüşlerine göre öğrencilerdeki teknoloji bağımlılığı. Psikiyatride Güncel Yaklaşımlar. 11(Suppl 1), 101-117.

32. Kwon, M., Lee, J.Y., Won, W.Y., Park, J.W., Min, J.A., Hahn, C., Gu, X. Choi, J.H. \& Kim, D.J. (2013). Development and validation of a smartphone addiction scale (SAS). PLoS One. $8(2), 1-7$.

33. Lee, W., Shin, L. \& Jeong, C. (2020). Leisure constraints and negotiation strategies of South Korean university students living in single-person households: A grounded theory exploration. World Leisure Journal. 62(4), 357-377.

34. Lyu, S.O. \& Oh, C.O. (2014). Recreationists' constraints negotiation process for continual leisure engagement. Leisure Sciences. 36(5), 479-497.

35. Lyu, S.O., Oh, C.O. \& Lee, H. (2013). The influence of extraversion on leisure constraints negotiation process. Journal of Leisure Research. 45(2), 233-252.

36. Öngel V. \& Tatlı H. S. (2020). Akademisyenlerin yaşam doyumları ve iş doyumlarını etkileyen iş kaynaklı faktörlerin incelenmesi. Journal of Higher Education and Science, 10(3), 461-473.

37. Öztürk, M. (2017). Teknolojiye Yerinde Yeterince. TBM Alan Kitaplığı Dizisi: 9 (7. Baskı). İstanbul: Kültür Sanat Basımevi.

38. Pavot, W. \& Diener, E. (2008). The satisfaction with life scale and the emerging construct of life satisfaction. The Journal of Positive Psychology, 3(2), 137-152.

39. Pescaru, T.G. (2017). Analysis of the main factors influencing student satisfaction towards the university environment. Journal of Educational Sciences and Psychology. VII(1), 40-50.

40. Pugh, S. (2017). Investigating the relationship between: Smartphone addiction, social anxiety, self-esteem, age and gender. BA Hons in Psychology Thesis. Dublin, Dublin Business School.

41. Ramia, I. \& Voicu, M. (2020). Life satisfaction and happiness among older Europeans: The role of active ageing. Social İndicators Research.

42. Rojas, M. (2006). Life satisfaction and satisfaction in domains of life: Is it a simple relationship?. Journal of Happiness Studies, 7(4), 467-497.

43. Soyer, F. (2019). Smartphone addiction and leisure constraints: College Students. İnternational Journal of Psychology and Educational Studies. 6(2), 26-34.

44. Soyer, F., Yıldız, N.O., Harmandar Demirel, D., Serdar, E., Demirel, M., Ayhan, C., \& Demirhan, O. (2017). Üniversite öğrencilerinin rekreatif etkinliklere katılımlarına engel teşkil 
eden faktörler ile katılımcıların yaşam doyumları arasındaki ilişkinin incelenmesi. Journal of Human Sciences, 14(2), 2035-2046.

45. Turan, E.B., Gülşen, D.B.A. \& Bilaloğlu, M. (2019). Kadın çalışanların yaşam doyumu ile boş zaman engelleri arasındaki ilişki: Akdeniz üniversitesi örneği. Gaziantep Üniversitesi Spor Bilimleri Dergisi. 4(1), 104-114.

46. Wang, P., Zhao, M., Wang, X., Xie, X., Wang, Y. \& Lei L. (2017). Peer relationship and adolescent smartphone addiction: The mediating role of self-esteem and the moderating role of the need to belong. Journal Behavioral Addictions, 6(4), 708-717.

47. Yam, F.C. \& İlhan, T. (2020). Modern çağın bütünsel teknolojik bağımlılığı: Phubbing. Psikiyatride Güncel Yaklaşımlar. 12(1), 1-15.

48. Yerlisu Lapa, T. \& Köse, E. (2018). Serbest zaman engelleri ile engellerle baş etme stratejileri arasındaki ilişkinin incelenmesi: Keşifsel bir çalışma. CBÜ Beden Eğitimi ve Spor Bilimleri Dergisi, 13(2), 356-375.

49. Yetim, Ü. (1993). Life satisfaction: A study based on the organization of personal projects, Social Indicators Research. 29(3), 277-289.

50. Young, K.S. (1997). What makes the internet addictive: Potential explanations for pathological internet Use. Paper presented at the 105th annual conference of the American Psychological Association, August 15, Chicago. 